\title{
The Effect of Learning Model and Critical Thinking Skills to Solve Motion Situation Problem Ability in Invasion Game
}

\author{
Anjar Muhamad Ikbal*, Yunyun Yudiana, Tite Juliantine \\ Sport Education Program, Postgraduate school \\ Universitas Pendidikan Indonesia \\ Bandung, Indonesia \\ *mikbalanjar@gmail.com
}

\begin{abstract}
Problem solving in invasion game is related activities thinking ability and decision ability to related motion situation problems that must solved in game situations. The purpose of this study to examine the effect of learning model and critical thinking skills to problem solving ability motion situation in invasion game. The research method uses factorial design with sampling is based on tests of critical thinking skills to determine sample groups. Data collection techniques using Game Test Situation (GTS). data analysis technique uses Two Way Anova to determine difference in overall influence and knowing interactions between independent variable with moderate variable. Hypothesis test uses Tukey test as a follow-up test for examine differences in the effect of each moderate variable. The results of this study concluded that use of the TGfU learning model with High critical thinking skill and low critical thinking skills have an influence to problem solving abilities motion situations in invasion game compared to PBL learning models.
\end{abstract}

Keywords-learning model; critical thinking; problem solving; invassion game

\section{INTRODUCTION}

The ability solve problems has an important to solve motion situation problem ability in invasion game. The ability to solve problems related to cognitive abilities and decision making to develop a series of effective actions playing situations, problem solving is a process in which an individual uses previously acquired knowledge, skills, and understanding to satisfy the demands of an unfamiliar situation [1]. Problem solving skills is it is the ability to identify the nature of a problem, deconstruct it (break it down) and develop an effective set of actions to address the challenges related to it [2]. The process of problem-solving motion situation in game invasion activities emphasize the relationship of complexity to the problem of motion situations related to individuals and teams that will be constantly faced during the game. the essence of sports games such as the possibility of solving at action a set countless of unforeseen and simultaneous problems with relating order [3]

Problem solving skills in invasion game can't be separated from the critical thinking skills possessed by students, because it has a relationship with cognitive behavioral processes. how individuals or groups identify or find effective ways to solve problems in game situations. Problem solving skill is defined as a cognitive-affective behavioral process through which an individual or group identifies or discovers effective means of coping with problem encountered [4].

Therefore, critical thinking skills are needed in the activities of invasion games, when students are faced with the problemsolving process to make decisions and are faced with several alternatives in determining decisions in play situations, there is this process students are at a higher level of thinking, because students consider several consequences of each decision critical thinking emerging from the philosophical tradition include reflective and reasonable thinking that is focused on deciding what to believe or do [5]. Critical thinking includes reflective actions and focused fair thinking related to deciding what to do is a combination of knowledge and performance in playing situations critical thinking as a blend of knowledge, attitude and performance in each individual which includes ability in comprehension skills, identifying hypothesis, inference, analysis and evaluating rational arguments [6]. Thus, critical thinking skills are needed in motion learning, because there is a cognitive process that will be reflected in the ability to decide in a playing situation faced with different problems. Effectiveness of Teaching Games for Understanding the Improvement of the Hockey Tactical Skills and the State of Self-Confidence among 16 Years Old Students [7]. The influence of problem-based learning on learning effectiveness in students of varying learning abilities within physical education [8]. The results of the study, TGfU and PBL learning models provide improvements towards tactical playing skills and self-confidence in various learning activities.

In the learning approach based on game activity, where execution of skills is not ignored, but developed in conjunction with an understanding of game strategies and tactics, the use of Teaching Game for Understanding (TGfU) learning models will provide direction related to student decisions in solving motion problems in game situations, TGfU approach is based on the constructivist concept that encourages students to participate in learning activities and develop their own understanding with the game situation [9]. learning situations in TGfU are aimed to develop tactical awareness, that is; the 
understanding or game sense required in addition to technique, for a player to become a competent and confident performer [10]. Learning situations with the TGfU model can develop tactical awareness regarding "WHAT" and "WHY" skills are performed from a game that is designed or conditioned towards tactics in various game situations, such as maintaining the area or directing the ball to the target.

Then the problem based learning (PBL) model is one of the learning models that can stimulate students to solve motion situation problems in the invasion game, this model raises problems at the beginning of learning develops into a student's thought that must be decided by using prior knowledge and skills, and eliminating errors that exist or have been done through individual and group work. PBL exploration in which they have to face problems and challenges before finally come to the conclusion on the best problem based learning practice that suits their needs and the learning styles of the students [11].

Learning experience becomes an implicit part of the learning process that is directed by students, where students build problem solving from their own experiences and interests both individually and in groups Problem-based learning involves small groups of students working in permanent groups to learn the course content within the framework of a realistic problem [12].

Therefore, use of the TGfU and PBL models can help students in solving problems of motion situations in invasion games activity, problems with motion situation encountered under conditions and a different game environment. Solve motion situation problems ability between TGfU and PBL models lies on students decision making, TGfU learning model decision making is based on tactical awareness related to "what" and "how" to deal with game situations, this is based on the concept in TGfU learning model that is game, game appreciation, tactical awareness, making appropriate decisions, skill execution dan performance [13]. While PBL model decision making is based on trial and error to determine decisions made based on previous learning experience, the implementation of learning is based on cycles problem scenario, identify fact, generate hypothesis, knowledge deficiencies, apply to knowledge [14].

\section{MethoD}

\section{A. Participant}

There were 92 students who were sampled in this study class X-IPA students who were around 15-17 years old taken from a population of 173 namely $27 \%$ of the upper group and $27 \%$ of the under group [15]. The sample in this study used the MIPA class because it is based on critical thinking skills with use various alternative systems of thought, while recognizing, judging, and looking for the relationship between all assumptions, implications, practical consequences. Communicate effectively with others in efforts to find solutions to complex problems, without affected by other people's thoughts on the topic in question.

\section{B. Procedures}

Beginning of learning, observations and tests of critical thinking skills are conducted to students to determine the research group. this research was carried out for six weeks with two meetings in one week, duration of time 135 minutes each time meeting according to the time in physical education learning curriculum. The treatment groups underwent the TGFU and PBL for 40 minutes in an invasion game to physical Education classes twice a week for four weeks. A pretest was conducted before the initiation of teaching approach, and a posttest was done after four weeks" (Lee, Rengasamy, Hooi, Varatharajoo, \& Azeez, 2015)

\section{Instruments}

The Game Test Situation Instrument (GTS) is used to identify tactical tasks that are not specific to invasion game activities in testing various hypotheses. GTS's main focus is to emphasize one specific, non-specific tactical task, in the form of identifying loopholes, finding empty spaces to attack and trying to win the ball from the opponent. This GTS is inseparable from the motorbike execution function of the student's ability or ability to execute the skills used. The central focus of the GTS was to emphasize one particular non-specific tactical task [16].

GTS instruments have an average value of instrument validity is 0.623 with a reliability value of 0.741 meaning that the instrument has a "reliable" level of reliability so that the observation sheet is made reliable. Thus, the above GTS instrument can be used to measure the ability to solve motion situation problems in an invasion game with different samples.

TABLE I. GAME TEST SitUATION INSTRUMENT [16]

\begin{tabular}{|l|l|}
\hline \multicolumn{1}{|c|}{ Item } & \multicolumn{1}{c|}{ Tactical task } \\
\hline Attacking the goal & Attacking the goal \\
\hline Taking ball near goal & $\begin{array}{l}\text { Setting up to attack } \\
\text { Penetrate get close to goal }\end{array}$ \\
\hline Playing together & $\begin{array}{l}\text { Maintaining possession of the ball } \\
\text { Attacking as a team, give and go }\end{array}$ \\
\hline Using gaps & Identification of gaps \\
\hline Feinting & Feinting \\
\hline Achieving advantage & Create offensive advantage \\
\hline Support and orienting & $\begin{array}{l}\text { Move without ball } \\
\text { Move to open space } \\
\text { Using space in attack } \\
\text { Off the ball movements }\end{array}$ \\
&
\end{tabular}

TABLE II.

GAME TEST SitUATION SCORING SCALE

\begin{tabular}{|l|l|l|}
\hline \multicolumn{1}{|c|}{$\begin{array}{c}\text { Quality of solutions to the situation } \\
\text { (using gaps or passing) }\end{array}$} & $\begin{array}{c}\text { Difficulty of the } \\
\text { situation }\end{array}$ & Scaling \\
\hline Perfect & Difficult & 10 \\
\hline Perfect & Intermediate & 9 \\
\hline Perfect & Easy & 8 \\
\hline Good, but one better solution exists & Difficult & 7 \\
\hline Good, but one better solution exists & Intermediate & 6 \\
\hline Satisfactory, two better solutions exist & Intermediate & 5 \\
\hline Satisfactory, two better solutions exist & Easy & 4 \\
\hline Insufficent, a bad solution was chosen & Difficult & 3 \\
\hline Insufficent, a bad solution was chosen & Intermediate & 2 \\
\hline Insufficent, a bad solution was chosen & Easy & 1 \\
\hline
\end{tabular}




\section{RESULT AND DISCUSSION}

The results of this study are related to the influence of the learning model and the ability to think critically about the ability to solve motion situation problems in invasion game, with the following data:

TABLE III. EFFECT OF LEARNING MODELS AND CRITICAL THINKING ABILITY ON ABILITY TO SOLVE MOTION SiTUATION PROBLEMS

\begin{tabular}{|l|l|l|l|l|l|}
\hline \multicolumn{1}{|c|}{ Source } & $\begin{array}{c}\text { Type III Sum of } \\
\text { Squares }\end{array}$ & \multicolumn{1}{c|}{ df } & \multicolumn{1}{c|}{$\begin{array}{c}\text { Mean } \\
\text { Square }\end{array}$} & F & Sig. \\
\hline $\begin{array}{l}\text { Corrected } \\
\text { Model }\end{array}$ & $2679.685^{\mathrm{a}}$ & 3 & 893.228 & 11.633 & .000 \\
\hline Intercept & 85400.098 & 1 & 85400.098 & 1112.175 & .000 \\
\hline Model & 222.272 & 1 & 222.272 & 2.895 & .034 \\
\hline CT & 530.880 & 1 & 530.880 & 6.914 & .010 \\
\hline Model * CT & 1926.533 & 1 & 1926.533 & 25.089 & .000 \\
\hline Error & 6757.217 & 88 & 76.787 & & \\
\hline Total & 94837.000 & 92 & & & \\
\hline Corrected Total & 9436.902 & 91 & & & \\
\hline
\end{tabular}

From the table above, that important values can be summarized as follows; (1) Corrected model is known Significance value of 0.00 (Sig.) $<0.05$ (Alfa) = Significant, thus the influence of all independent variables (learning models, critical thinking skills and the interaction of learning models with critical thinking skills or "learning models * critical thinking skills "together influence the dependent variable (problem-solving ability); (2) data from Intercept known significance value 0.00 (Sig.) $<0.05$ (Alfa) $=$ Significant, thus variable changes dependent without the influence of the existence of an independent variable, meaning that without the influence of the independent variable, the dependent variable can change its value. (3) data from the learning model is known Significance value of 0.034 (Sig.) $<0.05($ Alfa $)=$ significant, meaning the influence of the model on problem solving skills (4) The influence of critical thinking skills on the skills to solve problems in the motion situation in the model used $\mathrm{m}$ give effect, because the significance value is 0.010 (Sig.) $<0.05$ (Alfa) = Significant means that critical thinking skills have a significant effect. (5) Critical Model * The ability to solve the problem of motion situation obtained a significance value of 0.00 (Sig.) $<0.05$ (Alfa) means that there is an interaction between the learning model and critical thinking skills. Then the model error value is obtained (76,787), the TGfU and PBL models are good to be applied in learning the invasion game activity, especially in the ability to solve motion situation problems.

\section{A. Differences in the Ability to Solve Situation Problems}

\section{Between Invasion Models Between TGfU Learning and} $P B L$

As a whole TGfU learning model more influential compared with PBL models to help students in improving the ability to solve motion situation problems. Learning facts that by applying the TGfU learning model students are able to open space, find gaps, make effective attacks, can support friends in a team, students can be stimulated to the process of thinking in a game situation in invasion game. Then, differences to solve motion situations ability in invasion games activity, between TGfU and PBL learning models lies in the decisions made by students, if the TGfU learning model decision making is based on tactical awareness, while the PBL model decision making is based on trial and error from his learning experience. TGfU model to improve primary students tactical understanding and decision making in handball game [9]. In this case, TGfU model more influential because decision making is based on planned tactics and the introduction of various tactical problems at the beginning of learning will support resolving the problem of the motion situation, he faces changing game situations. TGfU's learning model centered on games that are closely related to sports with the constructivist nature of learning [17].

\section{B. Interaction between Learning Models and Critical Thinking Skills, Towards Troubleshooting Motion Situations in Invasion Games}

The use of TGfU and PBL learning models that emphasize the cognitive learning process, where the process will be supported by the critical thinking abilities that students have. In motion learning there is a situation that stimulates the learning process in the cognitive aspects of students. like when learning a student observes a friend who is playing a game, students pay attention to how to get the ball passed to their friends well. In the process of observing this cognition is activated, to then produce a good decision in every problem faced. Then the teacher gives a problem of movement which is how to pass to a friend who is being guarded by an opponent. At this stage there is a problem-solving process through critical thinking. Through a problem-based learning process physical education learning can stimulate critical thinking skills to solve problems it faces [18]. Thus, the use of cognitive learning models and critical thinking skills will help students in making decisions about motion situation problems in invasion game.

\section{There are Differences in the Ability to Solve Motion Situation Problems between TGfU and PBL Models for Students who Have High Critical Thinking Skills}

In a game situation, Critical thinking skills have a role to analyze a problem in a moving situation to the stage of finding a solution. Learning with the TGfU model can give direction related to decision making, starting with planning strategies that will be applied in the game, like designing an attack strategy or defense strategy so that students are able to carry out their duties and responsibilities in activities. For students who have high critical thinking skills will have an impact on the initiative in the game, like looking for space that eats, moves without a ball, tries to maintain the ball until the decision is related to the skills used. Then learning with PBL models, the beginning of the teacher's learning raises the problem of motion situations, the problem will be tested (trial $\&$ error). The problem of the motion situation will certainly be corrected by students from the experience of learning, then it will be corrected in subsequent learning activities. Associated with learning critical thinking in the TGfU model will have an impact on investigations conducted by students, the results of the investigation will be processed to be applied in the game situation. Critical thinking skills provided us with contextual information about the impact of the teacher's teaching on students levels of generation of creative response and 
refinement [19]. Thus, TGfU learning model more influential because the beginning of learning begins with strategic planning related to the tactics that will be used. And high critical thinking skills can provide initiatives related to skills decisions that will be used in play situations.

\section{There are Differences in the Ability to Solve Motion Situation Problems between TGfU and PBL Models for Students who Have Low Critical Thinking Skills.}

TGfU learning model which is based on the concept of game tactical understanding and planning playing tactics with the condition of students who have low critical thinking skills giving less initiative in the game, such as not optimizing gaps or opportunities, lacking in finding empty space, lazy in moving without the ball, and students not yet able to make appropriate decisions. While the PBL learning model emphasize at the beginning of learning by raising tactical problems in invasion game, giving effect to the ability to solve problems of motion situations, supported by students who have critical thinking skills to think related to solving problems of motion situations in games, then an investigation was conducted regarding the problems faced to the stage of implementation (trial \& error). As a result of the research PBL is accepted as the most effective instructional models in increasing and group working skills, being student centered, helping to construct the information, and performing meaningful learning [20]. The meaning students are invited to solve problems from the results of observing their learning experiences.

\section{CONCLUSION}

The focus of this research regarding the impact of the TGfU and PBL learning models and critical thinking skills regarding to solve motion situation problems ability in invasion game, The first conclusion, overall TGfU and PBL learning models influences to solve motion situations problem ability in invasion game because both models emphasize cognitive abilities to solve tactical problems in game situations. secondly that the learning model and critical thinking skills, has interactions to improve the ability to solve motion situation problems in invasion games, this is based on the use of learning models whose emphasis is on cognitive abilities supported by critical thinking skills will make decisions about effective motion situations. third for students who have high critical thinking skills, use of PBL and TGfU models influences the ability to solve motion situation problems in invasion games, but the TGfU model with high critical thinking skills is more influential because of the strategic planning of tactics to be used and provide initiatives related to decisions that will be used in play situations. Fourth conclusion, for students who have low critical thinking skills the use of PBL and TGfU models influences to solve motion situation problems ability. However, the PBL model has a greater influence on the ability to solve motion situation problems, because the use of PBL learning models' students are required to think high-level to solve problems situation in the game.

\section{ACKNOWLEDGMENTS}

This work was supported by the Universitas Pendidikan Indonesia and state Senior high school 1 Nagreg.

We also thank the Associate Editor and anonymous reviewers for their thoughtful comments during the review process. Finally, we are grateful to ATLANTIS PRESS and Proceedings of the 3rd ICSSHPE 2018.

\section{REFERENCES}

[1] B.R. Evans, "Editor's Perspective Article: Problem Solving Abilities and Perceptions in Alternative Certification Mathematics Teachers," Jnaac, vol. 7, no. 2, pp. 34-43, 2012 .

[2] A. Schultz, "How to Improve Your Problem-Solving Skills", QS Top Univ. (UK)RA, vol. 67, no. December, pp. 1-7, 2015.

[3] M.W. Metzler, Intructional Model For Physical Education, 6th ed. Scottsdale, Arizona: Holcomb Hathaway, 2005.

[4] K. Yigiter, "The Examining Problem Solving Skills and Preferences of Turkish University Students", Educ. Res. Int., vol. 1, no. 3, pp. 34-40, 2013.

[5] E.R. Lai, "Critical thinking: A literature review," Crit. Think., no. June, pp. 1-49, 2011

[6] N.R. Nezami, M. Asgari, and H. Dinarvand, "The Effect of Cooperative Learning On the Critical Thinking of High School Students", Tech. J. Eng. Appl. Sci., vol. 3, no. 19, pp. 1-7, 2013.

[7] W.S.S. Lee, S. Rengasamy, L.B. Hooi, C. Varatharajoo, and M.I.K. Azeez, "The Effectiveness of Teaching Games for the Improvement of the Hockey Tactical Skills and the State of Self-Confidence among 16 Years Old Students", vol. 9, no. 7, pp. 2270-2276, 2015

[8] Y.J. Luo, "The influence of problem-based learning on learning effectiveness in students of varying learning abilities within physical education”, Innov. Educ. Teach. Int., vol. 3297, no. November, pp. 1$11,2017$.

[9] M. Balakrishnan, S. Rengasamy, and M.S. Aman, "Effect of teaching games for understanding approach on students' cognitive learning outcome”, World Acad. Sci. Eng. Technol., vol. 77, no. 5, pp. 961-963, 2011.

[10] L.T. Ronglan and V. Ertesvag, "Becoming a Team Player? Learning Outcomes from Implementing a Team-Based TGfU Unit in High School”, J. Phys. Educ. Sport. Manag., vol. 2, no. 1, pp. 51-70, 2015

[11] H. Othman, B.M. Salleh, and A. Sulaiman, "An Innovative Learning Cycle in Problem-Based Learning", Int. J. Enhanc. Res. Educ. Dev., vol. 2, no. 3, pp. 50-57, 2014.

[12] J. a Amador and J.H. Gorres, "A Problem-Based Learning Approach to Teaching Introductory Soil Science.” J. Nat. Resour. Life Sci. Educ., vol. 33, no. July 2003, pp. 21-27, 2004.

[13] G.I. Nathan, S. Khanna, "Quasi experimental exploration of tgfu for decision making and skill execution.pdf”, MR International Journal of Applied Sciences, vol. 1, no. 1. pp. 44-51, 2014.

[14] C.E.H. Silver, "Problem-based learning: What and how do students learn?", Educ. Psychol. Rev., vol. 16, no. 3, pp. 235-266, 2004.

[15] A. James and A.P. Tangkudung, "TEACHING METHODS OF PRACTICE STYLE AND COMMAND”, J. Indones. Phys. Educ. Sport., vol. 1, no. 1, pp. 32-40, 2015.

[16] D. Memmert and S. Harvey, "Identification of non-specific tactical tasks in invasion games", Phys. Educ. Sport Pedagog., vol. 15, no. 3, pp. 287 $305,2010$.

[17] J.S. Rahayu, "Pemetaan penelitian TGfU 2000-2010", J. Pendidik. Jasm Indones., vol. 9, no. November, pp. 125-133, 2013.

[18] M. Rahmi, "Stimulasi Kemampuan Berpikir Kritis Melalu Pembelajaran Berbasis Masalah Pada Pendidikan Jasmani”, J. Pendidik. Jasm. dan Olahraga, vol. 2, no. 1, pp. 16-27, 2017 
[19] W. Chen and T. Cone, "Links Between Children's Use of Critical Thinking and an Expert Teacher's Teaching in Creative Dance", pp. $169-185,2003$.
[20] P. Celik, F. Onder, and I. Silay, "The effects of problem-based learning on the students' success in hysics course", Procedia - Soc. Behav. Sci., vol. 28, pp. 656-660, 2011. 